\title{
Perception of University of Tripoli, Faculty of Nursing Students on the Bachelor of Science in Nursing (BSN) Curriculum
}

\author{
Maria Cristina Arboleda-Tinay ${ }^{1}$, Dr. Ebtisam Ayad BenOmran², Evelyn Macasieb, Leonora Tilda Lesaca ${ }^{3}$, \\ Jane Fabian ${ }^{4}$, Joyce Juanita De Vera, RN, MAN ${ }^{5}$, Lamour Laureta, RN, MSN ${ }^{6}$ \\ $1,2,3,4,5,6$ Faculty of Nursing, University of Tripoli Tripoli, Libya
}

\begin{abstract}
The study aimed to determine the perception of University of Tripoli, Faculty of Nursing Students on the Bachelor of Science in Nursing (BSN) curriculum. Specifically, this study answered the following questions: 1) What are the Students' perception on the Basis of Curriculum Construction? 2) What are the Students' perception on the Basis of Curriculum Content? 3) What are the Students' perception on the Basis of Strategies?

The findings that the researcher was able to extract from the study were: 1) that the overall mean shows 3.92 which has a verbal interpretation of "Agree". The students should demonstrate a commitment to civic engagement, an understanding of various cultures, and the ability to apply ethical reasoning.

2) that the overall mean of 3.90 shows that most of the respondents had a verbal interpretation of "Agree" on the basis of curricular content from sequence to relevance in the nursing profession. 3) Most of the respondents with an overall mean of 3.69 and has a verbal interpretation of "Agree" on the basis of Teaching Strategies shows a wide range of instructional activities to facilitate learning. Based on these findings, the researcher was able to conclude that the University of Tripoli - Faculty of Nursing incorporated the principle on curriculum construction on its existing curriculum. However, All of the indicators on each component of the curriculum showed a verbal interpretation of "Agree", which allows for further enhancement of the curriculum.
\end{abstract}

KEY WORDS: Bachelor of Science in Nursing, Curriculum, Perception

\section{INTRODUCTION}

According to Ali Muftah Ebaid, Education Minister, Libya, Education has so much to do. He would like to change the curriculum, which he says needs to be focused on broader horizons that prepare students for life. He also would like to see workshops for crafts, which teachers are currently reluctant to try. But for the moment, he admits with a sigh, he has quite enough on his plate (Libya Herald, March 2014).

We are moving in an era of accelerating change in all walks of our life, and education is no exception it. We are developing and moving toward newer educational activities based on the knowledge of nursing science and technology. Evaluation is the step in the assessment process in which measures of quality and productivity are examined against some standard of performance. ${ }^{(1)}$

Program Evaluation encompasses a broader view of the educational program and examines component parts, including faculty, students, fiscal effectiveness, and curriculum and instructional outcomes. Curriculum evaluation is the process of determining the outcomes of student learning as a result of participation in a program or plan of learning. Curriculum evaluation involves establishing outcomes and verifying the extent to which these have been achieved. ${ }^{(2)}$

In nursing education, evaluations or judgments are made about performance (students), program effectiveness (nursing curriculum or program), instructional media (textbook, computer-assisted instruction program), or instruction (course, faculty).

Curriculum is the base in education on which the teaching-learning process is planned and implemented or in the totality of all the learning to which students are exposed their study in the school.

Curriculum is the means to which the school or college employs to discharge its' responsibility towards the individual and the society. A sequence of potential experiences is set up in the school or college for the purposes of disciplining students in group ways of thinking and acting. The set of experiences is referred to as the "curriculum". ${ }^{(3)}$

As University of Tripoli, Faculty of Nursing struggles to provide quality education, I deemed it necessary to determine the perception of the students in the curriculum as this is one of the foundational component of the nursing program. This study is limited to the perception of the students as to the basis of construction, content and strategies on delivering the curriculum. 


\section{International Journal of Current Science Research and Review}

ISSN: 2581-8341

Volume 04 Issue 08 August 2021

DOI: 10.47191/ijesrr/V4-i8-11, Impact Factor: 5.825

IJCSRR@ 2021

WWw.ijcsrr.org

Though this is not enough to form the basis of evaluation, determining the perception of students, as one of the stakeholders of education is vital to note at in the thorough process of curriculum evaluation.

\section{METHODS}

This study employed the Descriptive Normative Survey method of research. "The study made used of structured questionnaire as an instrument utilizing the likert scale. The data will be treated statistically using the weighted mean. The study is limited to levels 2, 3, and 4 students. This is for the primary reason that the level 1 students are not yet exposed to Related Learning Experience (RLE) in the hospital with which some items are found in the questionnaire. In today's educational and health care environment, it is essential to gather thoughts and ideas about the curriculum from diverse sources, which includes the students. This is to ensure that their voice is heard regarding needed content and effective ways of delivering it (Keating, 2006). Stratified random sampling was used to select the samples. The findings of this study will be utilized in the annual planning of the faculty as well as in the curriculum review and evaluation.

The questionnaire to be used in the interview is composed of three (3) parts, the student's perception on the basis of curriculum construction, content and strategies. They will be asked to rate in a scale of 1-5, 1 being the lowest and 5 as the highest. Communication was sent to the Dean of the Faculty of Nursing to seek perusal for the conduct of the study. After the consent had been sought, the questionnaires was distributed to Levels 2-4 nursing students during Registration Day. After the data collection, the data was treated statistically.

\section{RESULTS}

Detailed analysis of Table 1 showing the frequency and percentage of the student's perception on the basis of curriculum construction disclosed an overall mean of 3.92 which has a verbal interpretation of "Agree".

Cursory inspection of Table 2 reflecting the results of the mean of the Student's Perception on the Basis of Curriculum Content disclosed that most of the indicator shows a verbal interpretation of "Agree", with an overall mean of 3.90.

Detailed analysis of Table 3 reflecting the results of the mean of the Student's Perception on the Basis of Teaching Strategies disclosed that most of the indicator shows a verbal interpretation of "Agree" with an overall mean of 3.69.

Table 1. Mean and Verbal Interpretation of the Students' Perception on the Basis of Curriculum Construction

\begin{tabular}{l|l|l}
\hline \hline Indicator & Mean & $\begin{array}{l}\text { Verbal } \\
\text { Interpretation }\end{array}$ \\
\hline
\end{tabular}

A. Curriculum Construction

1. The curriculum is centered on the learners.

3.90 Agree

2. The curriculum includes knowledge and skills which

3.96 Agree the student requires for his present and future life endeavour.

3. The Faculty reflect all significant characteristic in the 3.86 Agree life of community in its natural setting.

4. The curriculum consists of purposeful activities and 3.96 Agree meaningful experiences.

5. The curriculum provides direct instruction.

4.35 Agree 


\section{International Journal of Current Science Research and Review}

ISSN: 2581-8341

Volume 04 Issue 08 August 2021

DOI: 10.47191/ijesrr/V4-i8-11, Impact Factor: 5.825

IJCSRR@ 2021

www.ijcsrr.org

6. The curriculum promotes democratic values.

3.54 Agree

7. The curriculum achieves the holistic growth of the

3.84 Agree students. (Knowledge, Skills and Attitude)

\begin{tabular}{ccc|c}
\hline \hline Overall & & $\mathbf{3 . 9 2}$ & Agree \\
\hline Legend: & Unit Weight & Weighted Mean Interval & Verbal Interpretation \\
5 & $4.51-5.00$ & Strongly Agree \\
4 & $3.51-4.50$ & Agree \\
3 & $2.51-3.50$ & Uncertain \\
2 & $1.51-2.50$ & Disagree \\
1 & $0.51-1.50$ & Strongly Disagree
\end{tabular}

Table 2. Mean and Verbal Interpretation of the Students' Perception on the Basis of Curriculum Content

\begin{tabular}{l|l|l}
\hline \hline Indicator & Mean & $\begin{array}{l}\text { Verbal } \\
\text { Interpretation }\end{array}$ \\
\hline
\end{tabular}

B. Curriculum Content

1. The curricular content is in order and right

3.93 Agree sequence. Gradually progress from simple to complex, concrete to abstract, normal to abnormal.

2. The Faculty reflect all significant characteristic in the life of community in its natural setting.

3. The number of hours allotted is enough for the content.

4. Clinical experiences and practices proportionate to the number of students.

5. Provides opportunity for the learner to integrate various learning experiences with new ones. correlate with clinical practice. students should learn vital to that of being a nurse in the future.

8. The curriculum covers subjects that are relevant to the nursing profession.

\begin{tabular}{l|c|c|}
\hline \hline Overall & 3.90 & Agree \\
\hline
\end{tabular}




\section{International Journal of Current Science Research and Review}

ISSN: 2581-8341

Volume 04 Issue 08 August 2021

DOI: 10.47191/ijesrr/V4-i8-11, Impact Factor: 5.825

IJCSRR@ 2021

www.ijcsrr.org

\begin{tabular}{|c|c|c|c|}
\hline Legend: & $\begin{array}{l}\text { Unit Weight } \\
5\end{array}$ & $\begin{array}{l}\text { Weighted Mean Interval } \\
4.51-5.00\end{array}$ & $\begin{array}{l}\text { Verbal Interpretation } \\
\text { Strongly Agree }\end{array}$ \\
\hline & 4 & $3.51-4.50$ & Agree \\
\hline & 3 & $2.51-3.50$ & Uncertain \\
\hline & 2 & $1.51-2.50$ & Disagree \\
\hline & 1 & $0.51-1.50$ & Strongly Disagree \\
\hline
\end{tabular}

Table 3. Mean and Verbal Interpretation of the Students' Perception on the Basis of Strategies

\begin{tabular}{l|l|l}
\hline \hline Indicator & Mean & $\begin{array}{l}\text { Verbal } \\
\text { Interpretation }\end{array}$ \\
\hline
\end{tabular}

A. Strategies

1. There is a wide range of creative instructional

3.71 Agree

material designed for all learners.

2. Instructors are trained in the effective use of

3.64

Agree

instructional materials.

3. Instructors employ creative and purposeful activities to facilitate learning.

Agree

\begin{tabular}{|c|c|c|c|c|}
\hline \multirow[b]{2}{*}{ Legend: } & Overall & & 3.69 & Agree \\
\hline & Unit Weight & Weighted Mean Interval & \multicolumn{2}{|c|}{ Verbal Interpretation } \\
\hline & 5 & $4.51-5.00$ & & trongly Agree \\
\hline & 4 & $3.51-4.50$ & & Agree \\
\hline & 3 & $2.51-3.50$ & & Jncertain \\
\hline & 2 & $1.51-2.50$ & & Disagree \\
\hline & 1 & $0.51-1.50$ & & trongly Disagree \\
\hline
\end{tabular}

\section{DISCUSSION}

School of Nursing prepares the professional practitioner of nursing, must be concerned with the development of a nurse who will be interested in the health and other related aspects of the community. This means that the college must provide opportunities for the development of Knowledge, Skills and Attitudes which will make this possible. ${ }^{(4)}$

The students are considered a whole individual whose ability to learn and adjust is conditioned not only by their intellectual capacity but also their emotional make up, attitudes, social relationships and mental and physical conditions.

Curriculum should be centered on the students. Therefore, curriculum should be framed in accordance with the student and his needs. The curriculum should also be community centered. The student is an heir to the society he is born. The curriculum must be determined by the purpose of the society.

Curriculum must be appropriately organized to move learners along a continuum from program entry to program completion. The principle of vertical organization guides both the planning and evaluation of the curriculum. This principle provides the rationale for the sequencing of curricular content elements. ${ }^{(3)}$

Nursing faculty often use depth and complexity as sequencing guides. Content areas may occur in subsequent levels of the curriculum at a level of greater depth and complexity. Knowledge is acquired by proceeding from data and concepts to principles and constructs. 


\section{International Journal of Current Science Research and Review}

ISSN: 2581-8341

Volume 04 Issue 08 August 2021

DOI: 10.47191/ijcsrr/V4-i8-11, Impact Factor: 5.825

IJCSRR@ 2021

wWw.ijcsrr.org

In evaluation of the curriculum, there is a need to assess for increasing depth and complexity to determine whether the sequencing was useful to learning and progressed to the desired outcomes. ${ }^{(2)}$

Determination of whether course and level objectives demonstrate sequential learning across the curriculum can be used as test for vertical organization.

The principle of linear congruence, sometimes called horizontal organization, assists faculty in determining which courses should precede and follow others and which should be concurrent. The concept of sequencing follows the principle of moderate novelty in that new information and experiences should not be presented until existing knowledge has been assimilated (Rabinowitz \& Schubert, 1991).

Evaluation of teaching effectiveness involves assessment of teaching strategies (including instructional materials), assessment of methods used to evaluate student performance, and assessment of student learning. ${ }^{(4)}$

Information and instructional technology must be up-to-date and support the achievement of program goals. Productivity is directly related to the technology available to students and faculty, which enables them to meet their responsibilities and to create a dynamic learning environment.

In planning programs, it is useful to have a variety of teaching and learning methods to meet the diverse learning needs of the target audience. Sparling (2001) presents specific suggestions for enhancing learning such as building confidence through a supportive learning environment, accommodating a variety of learning styles, and providing opportunities to practice new skills. (5)

\section{CONCLUSIONS}

It can be said that each component of the curriculum showed that the University of Tripoli - Faculty of Nursing incorporated the principle on curriculum construction on its existing curriculum. However, since each indicators got a verbal interpretation of "Agree", it provides an avenue for further enhancement of the curriculum. The Principle on teaching strategies got the lowest mean and would be needing keen attention.

\section{REFERENCES}

1. Basavanthappa, BT., Nursing Education, $1^{\text {st }}$ edition, Jaypee Brothers Medical Publishers, 2003.

2. Billing, Diane M. \& Halstead, Judith A., Teaching in Nursing: A Guide for Faculty, $3^{\text {rd }}$ edition, Saunders Elsevier, 2009.

3. Keating, Sarah B., Curriculum Development and Evaluation in Nursing, Lippincott Williams \& Wilkins, 2006.

4. American Association of Critical Nurses, Core Curriculum for Progressive Care Nursing, Saunders Elsevier, 2008.

5. Zerwekh, Joann \& Claborn, Jo Carol., Nursing Today: Transition and Trends, $5^{\text {th }}$ edition, Saunders Elsevier, 2006.

Cite this Article: Maria Cristina Arboleda-Tinay, Dr. Ebtisam Ayad BenOmran, Evelyn Macasieb, Leonora Tilda Lesaca, Jane Fabian, Joyce Juanita De Vera, RN, MAN, Lamour Laureta, RN, MSN (2021). Perception of University of Tripoli, Faculty of Nursing Students on the Bachelor of Science in Nursing (BSN) Curriculum. International Journal of Current Science Research and Review, 4(8), 947-951 